\title{
The Effect of Salicylate on the Metabolism of
}

\section{Normal and Stimulated Human Lymphocytes In Vitro}

\author{
Lauren M. Pachman, Nancy B. Esterly, and Raymond D. A. Peterson \\ From The Variety Club Research Center of the La Rabida-University of \\ Chicago Institute and the Department of Pediatrics, University of Chicago, \\ Chicago, Illinois 60649
}

\begin{abstract}
A B S T R A C T The effect of salicylate on the metabolism of peripheral blood lymphocytes in tissue culture was investigated. Lymphocytes incubated with sodium salicylate at a concentration of $30 \mathrm{mg} / 100 \mathrm{ml}$ showed increased glucose consumption, lactic acid production, and oxygen consumption, evidence for uncoupling of oxidative phosphorylation. No decrease in cell number or viability (trypan blue dye exclusion) was noted in salicylatetreated cultures. Normal DNA, RNA, and total protein synthesis measured by radioisotope incorporation was depressed in the salicylate-treated cultures. Increased DNA synthesis after the addition of a mitogen (PHA) or antigen (PPD) to the culture was strikingly suppressed by salicylate. The degree of suppression was proportional to the concentration of salicylate used. The effect on RNA and protein synthesis in stimulated lymphocytes was much less pronounced. Acetylsalicylic acid was found to be as active as sodium salicylate in suppressing DNA synthesis, but the $p-\mathrm{OH}$ congener $(p-\mathrm{OH}$ benzoic acid) did not alter cell respiration, glycolysis, viability, or DNA synthesis. The salicylate effect was reversible as evidenced by return of cellular reactivity upon removal of the drug from the media.
\end{abstract}

\section{INTRODUCTION}

Salicylates are the treatment of choice for rheumatoid arthritis and rheumatic fever without carditis $(1,2)$, although their mechanism of action remains unknown. After ingestion, aspirin is rapidly hydrolyzed to the free acetyl radical and salicylate (3-6). Blood levels of

This was presented in part at the Federation of American Societies for Experimental Biology, April, 1969, Atlantic City, N. J.

Dr. Esterly's present address is the Department of Dermatology, University of Illinois, College of Medicine, Chicago, I11. 60612 .

Received for publication 25 May 1970 and in revised form 18 August 1970. salicylate are monitored and considered therapeutic at concentrations of $20-30 \mathrm{mg} / 100 \mathrm{ml}$, and symptomatic relief is usually obtained.

Pharmacological studies of the effect of salicylate on various tissues and mitochondria indicate that it uncouples oxidative phosphorylation (7-11), affecting primarily aerobic phosphorylation (12). Previous investigation of the carbohydrate metabolism of lymphocytes, one of the components of the inflammatory cycle, has shown that their oxidative phosphorylation could be uncoupled by 2,4-dinitrophenol (13). The present study was, therefore, initiated to determine some of the effects of salicylate on the metabolism of normal and stimulated human lymphocytes in vitro.

\section{METHODS}

\section{Preparation of lymphocytes}

Heparinized (10 $\mathrm{U}$ of Liquaemin sodium [Organon Inc., West Orange, N. J.] per $\mathrm{ml}$ ) peripheral blood was obtained from healthy adult human donors as previously outlined (13). Gentran $6 \% \mathrm{w} / \mathrm{v}$ in $0.9 \%$ sodium chloride (Dextran 70, Travenol Laboratories, Inc., Morton Grove, Ill.) was added to a final concentration of $0.6 \%$ and the blood-dextran mixture was sedimented in an inverted syringe at $37^{\circ} \mathrm{C}$. The leukocyte-rich plasma layer was removed and applied to a column consisting of an equal volume of absorbent cotton (Red Cross, Johnson \& Johnson, New Brunswick, N. J.). After elution with Hank's solution, the effluent, containing mononucleated cells, red cells (not more than a $3: 1$ ratio), and no more than $1 \%$ polymorphonuclear leukocytes, was concentrated and suspended in media.

\section{Conditions of culture}

In short-term experiments measuring respiration, the cells were suspended in phosphate buffer containing $1000 \mu \mathrm{g}$ of glucose per $\mathrm{ml}$ at a concentration of $2.5 \times 10^{7} / \mathrm{ml}$, and maintained at $37^{\circ} \mathrm{C}$

In long-term experiments, lasting 3 or 5 days, the lymphocytes were suspended in complete Eagle's Minimal Essential Medium spinner modification (CMEM, all components from Gibco, Grand Island, N. Y.) containing $20 \%$ heat-inactivated 
TABLE I

In Vitro Effects of Sodium Salicylate and p-OH Benzoic Acid on Lymphocyte Respiration, Glycolysis, and Viability

\begin{tabular}{|c|c|c|c|c|c|c|c|c|}
\hline \multirow{2}{*}{\multicolumn{2}{|c|}{ Freshly isolated cells }} & \multirow{3}{*}{; } & \multicolumn{6}{|c|}{ After 3 days in vitro } \\
\hline & & & \multirow[b]{2}{*}{ Glucose } & \multirow[b]{2}{*}{$P$} & \multirow[b]{2}{*}{ Lactic acid $\ddagger$} & \multirow[b]{2}{*}{$P$} & \multirow[b]{2}{*}{ Cell count§ } & \multirow{2}{*}{$\begin{array}{c}\text { Per cent } \\
\text { Trypan } \\
\text { blue } \\
\text { negative }\end{array}$} \\
\hline Addition & Respiration* & & & & & & & \\
\hline Saline & $\underset{(7) \mathbb{I}}{3.05 \pm}$ & & $\begin{array}{c}1.56 \pm 0.31 \\
(8)\end{array}$ & & $\begin{array}{c}2.49 \pm 0.16 \\
(8)\end{array}$ & & $\begin{array}{c}1.99 \pm 0.085 \\
(10)\end{array}$ & $\begin{array}{l}83.1 \pm 1.50 \\
\quad(10)\end{array}$ \\
\hline $\begin{array}{l}\text { p-OH Benzoic Acid, } \\
30 \mathrm{mg} / 100 \mathrm{ml}\end{array}$ & $\begin{array}{l}3.02 \pm 0.12 \\
\text { (3) }\end{array}$ & $>0.50$ & $\begin{array}{l}1.90 \pm 0.56 \\
(8)\end{array}$ & $>0.50$ & $\begin{array}{l}2.76 \pm 0.34 \\
\quad(8)\end{array}$ & $>0.40$ & - & - \\
\hline $\begin{array}{l}\text { Sodium salicylate, } \\
30 \mathrm{mg} / 100 \mathrm{ml}\end{array}$ & $\begin{array}{c}4.13 \pm 0.12 \\
(7)\end{array}$ & $<0.001$ & $\begin{array}{c}4.08 \pm 0.54 \\
(8)\end{array}$ & $<0.005$ & $\begin{array}{c}3.50 \pm 0.47 \\
(8)\end{array}$ & $<0.05$ & $\begin{array}{c}1.81 \pm 0.57 \\
\quad(10)\end{array}$ & $\begin{array}{c}80.3 \pm 1.30 \\
\quad(10)\end{array}$ \\
\hline $\begin{array}{l}30 \mathrm{mg} / 100 \mathrm{ml} \text { of } \\
\text { sodium salicylate } \\
\text { followed by } \\
2 \times 10^{-4} \mathrm{M} \mathrm{KCN}\end{array}$ & $\begin{array}{c}0.46 \pm 0.06 \\
(3)\end{array}$ & & - & & - & & - & - \\
\hline
\end{tabular}

The effect of sodium salicylate and $p-O H$ benzoic acid on the oxygen consumption of freshly isolated lymphocytes and on cellular glycolysis and viability after 3 days in vitro.

* $\mathrm{m} \mu$ moles of $\mathrm{O}_{2}$ per $10^{7}$ per min; $\mathrm{RBC}$ present in not more than 1:1 ratio.

$\ddagger$ Change in concentration in mmoles $/ 10^{7}$ cells.

Times $10^{6}$ cells per culture.

II Mean \pm SE.

I Number of experiments, triplicate observations in each.

fetal calf serum $\left(56^{\circ} \mathrm{C}\right.$ for $\left.30 \mathrm{~min}\right), 2 \mathrm{mmoles} / \mathrm{ml}$ of L-glutamine, $50 \mathrm{U} / \mathrm{ml}$ of penicillin, and $50 \mu \mathrm{g} / \mathrm{ml}$ of streptomycin. The cell suspension was adjusted to a final concentration of $2.5-3.0 \times 10^{8} / \mathrm{ml}$ and dispensed into $16 \times 100 \mathrm{~mm}$ disposable flint glass tissue culture tubes (Bellco Glass, Inc., Vineland, N. J.). The cultures were maintained with loosely fitted caps (Kaput, Bellco) in a 5\% CO=95\% air incubator at $37^{\circ} \mathrm{C}$ for the appropriate time periods. Phenol red-free media was used in experiments in which glucose, lactic acid, or salicylate determinations were performed.

\section{Experimental design}

Freshly isolated lymphocytes in high concentrations were used to evaluate the immediate effect of salicylate and $p$-OH benzoic acid on respiration. In longer-term studies, lower cell concentrations were prepared in triplicate for each additive. After three days in vitro, total cell number and viability was determined, and the supernatant media obtained for glucose, lactic acid, and salicylate content.

The effect of salicylate on lymphocyte nucleic acid and protein synthesis in vitro was measured in duplicate cultures with and without the simultaneous addition of mitogen (PHA or PPD). In experiments using PHA, the appropriate tritiated precursor was added to the cultures on day 1,2 , and 3 ; in those using PPD, the label was added on day 1,3 , and 5 .

\section{Determination of cell viability}

Cell viability was assessed by exclusion of $1 \%$ trypan blue dye (13). 50 cells were counted from each of quadruplicate tubes containing either salicylate-treated or control cells. The slides were coded during preparation and evaluated independently by two observers. Total white blood cell counts were performed using Hayem's solution and a standardized Neubauer hemocytometer.

\section{Additions to cultures}

Salicylates. Sodium salicylate (Matheson, Coleman \& Bell, Norwood, Ohio) was dissolved in phosphate-buffered saline (PBS) and added to the cell suspensions in the stated concentrations. Acetylsalicylic acid (Aspirin, Matheson, Coleman \& Bell) $30 \mathrm{mg} / 100 \mathrm{ml}$ in $\mathrm{PBS}$ or parahydroxide benzoic acid ( $p$-OHBA, Aldrich Chemical Co., Inc., Milwaukee, Wis.) $30 \mathrm{mg} / 100 \mathrm{ml}$ in PBS were used in the experiments as indicated. The $\mathrm{pH}$ of the starting media was unaltered by the concentrations of sodium salicylate used; after addition of $p-\mathrm{OH}$ benzoic acid or aspirin, the $\mathrm{pH}$ was adjusted to 7.4. The concentration of salicylate in the media was determined by the method of Trinder (14).

Mitogenic agents. Phytohemagglutinin (PHA, Burroughs Welcome \& Co., London, England, lot No. 9312) was used as a nonspecific mitogen in a final concentration of $20 \mu 1 / \mathrm{ml}$ of tissue culture media. Purified tuberculin protein (PPD, supplied by Dr. Fisher of Parke, Davis \& Co., Detroit, Mich.) was used as an antigenic stimulus in a final concentration of $10 \mu \mathrm{g} / \mathrm{ml}$ to achieve maximal stimulation of lymphocytes from previously assayed skin test positive donors.

\section{Chemical determinations}

Oxygen consumption. Oxygen consumption was determined in a microcuvette with a Clarke Oxygen Electrode (Gilson Medical Electronics Inc., Middleton, Wis.) and expressed as $\mathrm{m} \mu$ moles $/ 10^{7}$ cells per $\min (13)$. The drugs were added to the microcuvette and the effect on cell respiration was recorded over a $10 \mathrm{~min}$ period.

Glucose consumption and lactic acid production. Glucose levels were determined (Glucostat, Worthington Biochemical Corp., Freehold, N. J.) and the lactic acid content of the media was measured (Stat pack, Calbiochem, Los Angeles, Calif.) at the beginning and the end of the culture period, 
and the change in each was expressed as mmoles $/ 10^{7}$ cells (13).

DNA synthesis. $1 \mu \mathrm{Ci}$ of methylthymidine- ${ }^{3} \mathrm{H}$, specific activity $1.9 \mathrm{Ci} / \mathrm{mmole}$ (Schwarz Bio Research Inc., Orangeburg, N. Y.), was added to each culture on the designated day. After $4 \mathrm{hr}$, the culture tubes were centrifuged at $150 \mathrm{~g}$ for $10 \mathrm{~min}$ at $4^{\circ} \mathrm{C}$ and the supernatant was removed. The cells were frozen and thawed once and extracted for DNA twice with cold $5 \%$ trichloroacetic acid (TCA) and twice with cold absolute methanol. Each precipitate was dissolved in $0.3 \mathrm{ml}$ NCS solubilizer (Nuclear-Chicago, Des Plaines, I11.) and $10 \mathrm{ml}$ of scintillator, Liquifluor (New England Nuclear Corp., Boston, Mass.), containing $6 \mathrm{~g}$ of 2,5-diphenyloxazole and $0.075 \mathrm{~g}$ of $p$-bis 2-(5-phenyloxazoly1) benzene per liter of toluene. The radioactivity of the samples was measured in a Packard Tricarb model No. 3320 (Packard Instrument Co., Inc., Downers Grove, Ill.).

$R N A$ synthesis. $5 \mu \mathrm{Ci}$ of 5 -uridine- ${ }^{3} \mathrm{H}$, specific activity 4 $\mathrm{Ci} / \mathrm{mmole}$ (Schwarz Bio Research), were added to each culture for a $4 \mathrm{hr}$ period as indicated. The cells were recovered, frozen, and thawed, and bovine serum albumin (BSA, Armour Pharmaceutical Co., Chicago, Ill.) 500 $\mu \mathrm{g} /$ tube, was added as carrier. RNA was extracted according to the method of Kay and Korner (15) ; the final precipitate was dissolved in NCS and the radioactivity measured as above.

Total protcin synthesis. Lymphocytes were cultured in leucine-free CMEM (Gibco) and each tube was pulsed with $5 \mu \mathrm{Ci}$ of 4,5 -leucine- ${ }^{3} \mathrm{H}$, specific activity $6 \mathrm{Ci} / \mathrm{mmole}$ (Schwarz Bio Research). After $4 \mathrm{hr}$, the cells were recovered, BSA $500 \mu \mathrm{g} /$ tube was added as carrier, and the protein extracted, according to the method of Schneider (16), solubilized with NCS, and the radioactivity determined.

\section{RESULTS}

Respiration, glycolysis, and viability. Salicylate increased the respiration of freshly isolated lymphocytes by $31 \%$; this stimulation was inhibited by cyanide, leaving a cyanide-resistant respiration of $15 \%$ (Table I). No change in lymphocyte oxygen consumption was observed with addition of comparable concentrations of $p$-OH benzoic acid. Salicylate, but not $p$-benzoic acid, increased cellular glucose consumption by $161 \%$, and lactic acid production by $40 \%$ after 3 days in vitro without altering the viability or total number of mononuclear cells.

Nucleic acid and protein synthesis. The suppressive effect of salicylate on DNA synthesis in control cultures, and those stimulated with PHA or PPD was dose related (Table II). The levels of salicylate in the test media remained constant throughout the culture period. Individuals varied in their degree of sensitivity to salicylate, but multiple determinations on consecutive cell samples from a given donor were consistent. Aspirin in a concentration of $30 \mathrm{mg} / 100 \mathrm{ml}$ suppressed DNA synthesis. A similar concentration of $p-\mathrm{OH}$ benzoic acid was without effect.

RNA and total protein synthesis in control cells, and those stimulated by PHA or PPD were measured daily (Table III). DNA synthesis was determined on day 3 from PHA-treated cells and on day 5 for antigensensitive cells exposed to $P P D$. In vitro concentrations of $30 \mathrm{mg} / 100 \mathrm{ml}$ of salicylate inhibited DNA synthesis by $94 \%$ in both PPD- and PHA-stimulated cells. RNA and total protein synthesis were both suppressed to a lesser extent in cells responding to either PHA or PPD.

The effect of salicylate on RNA synthesis was reversible, as seen in Table IV, which shows data from one of four experiments. The initial culture media containing PHA, salicylate, PHA and salicylate, or saline alone was removed after $24 \mathrm{hr}$, and replaced with fresh media containing either $30 \mathrm{mg} / 100 \mathrm{ml}$ of sodium salicylate or saline. Decrease in incorporation of tritiated uridine $48 \mathrm{hr}$ later (after a total of 3 days in vitro) was dependent on the continued presence of salicylate in the media. Removal of salicylate from the media resulted in RNA synthesis equal to that found in cultures treated with PHA alone.

TABLE II

Suppression of Stimulated Lymphocyte DNA Synthesis In Vitro by Salicylate

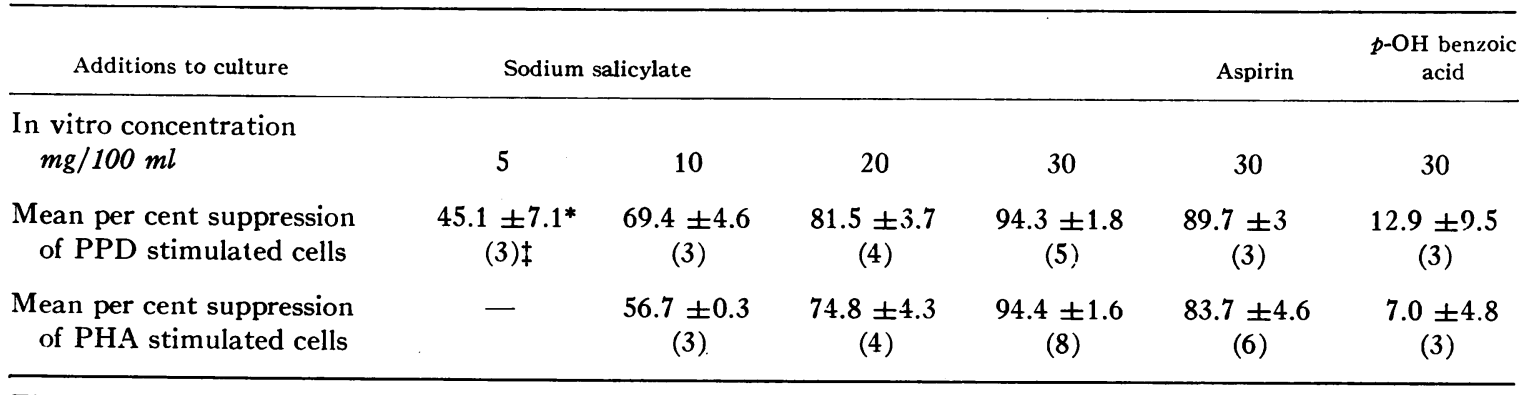

The effect of various doses of salicylate on in vitro DNA synthesis assayed by uptake of tritiated thymidine in cells stimulated by PHA (measured after 3 days of culture) or PPD (measured after 5 days in vitro).

* Mean \pm SE.

$\ddagger$ Number of experiments, triplicate observations in each. 
TABLE III

Salicylate Suppression of Lymphocyte Nucleic Acid and Protein Synthesis In Vitro

\begin{tabular}{|c|c|c|c|c|c|}
\hline \multirow{2}{*}{$\begin{array}{l}\text { Substance } \\
\text { added }\end{array}$} & \multirow{2}{*}{$\begin{array}{l}\text { Mean per cent } \\
\text { suppression by } \\
\text { salicylate of : }\end{array}$} & \multicolumn{4}{|c|}{ Days in culture } \\
\hline & & 1 & 2 & 3 & 5 \\
\hline PHA & Total protein & $\begin{array}{c}49.50 \pm 9.4^{*} \\
(4) \ddagger\end{array}$ & $\begin{array}{c}38.40 \pm 3.9 \\
(5)\end{array}$ & $\begin{array}{c}62.50 \pm 1.2 \\
(4)\end{array}$ & - \\
\hline “ & RNA & $\begin{array}{c}36.70 \pm 10.5 \\
(4)\end{array}$ & $\begin{array}{c}54.14 \pm 6.2 \\
(7)\end{array}$ & $\begin{array}{c}65.20 \pm 5.0 \\
(8)\end{array}$ & 一 \\
\hline “ & DNA & - & - & $\begin{array}{c}94.55 \pm 1.6 \\
(8)\end{array}$ & - \\
\hline PPD & Total protein & $20.80 \pm 2.4$ & - & $51.12 \pm 6.6$ & $79.54 \pm 3.5$ \\
\hline “ & RNA & $\begin{array}{c}26.34 \pm 7.3 \\
(3)\end{array}$ & - & $\begin{array}{c}57.13 \pm 7.2 \\
(4)\end{array}$ & $\begin{array}{c}80.82 \pm 3.4 \\
(4)\end{array}$ \\
\hline “ & DNA & - & - & - & $\begin{array}{c}94.28 \pm 1.8 \\
(5)\end{array}$ \\
\hline Saline & Total protein & $\begin{array}{c}22.75 \pm 3.8 \\
(8)\end{array}$ & $\begin{array}{c}24.25 \pm 7.6 \\
(4)\end{array}$ & $\begin{array}{c}31.53 \pm 4.2 \\
(8)\end{array}$ & $\begin{array}{c}70.24 \pm 4.2 \\
(4)\end{array}$ \\
\hline “" & RNA & $\begin{array}{c}12.94 \pm 5.9 \\
(8)\end{array}$ & $\begin{array}{c}7.14 \pm 12.8 \\
(7)\end{array}$ & $\begin{array}{c}29.00 \pm 7.8 \\
(8)\end{array}$ & $\begin{array}{c}57.5 \pm 3.4 \\
(4)\end{array}$ \\
\hline “ & DNA & - & - & $\begin{array}{c}79.96 \pm 2.5 \\
(8)\end{array}$ & $\begin{array}{c}78.15 \pm 3.9 \\
(4)\end{array}$ \\
\hline
\end{tabular}

The suppression by in vitro concentrations of $30 \mathrm{mg} / 100 \mathrm{ml}$ of sodium salicylate of DNA synthesis (measured by uptake of tritiated thymidine), RNA synthesis (measured by uptake of tritiated uridine), and total protein synthesis (evaluated by uptake of tritiated leucine) in cells treated with PHA (assayed on day 1, 2, and 3) or PPD (assayed on day 1, 3, and 5) and their controls.

$*$ Mean \pm SE.

$\ddagger$ Number of experiments, duplicate observations in each.

\section{DISCUSSION}

Salicylate affects aerobic oxidative phosphorylation in differing ways, depending on the source of the tissue or the mitochondrial preparation (9-12). In the present study, the increased respiratory rate of lymphocytes after the addition of salicylate was diminished to endogenous levels by cyanide, suggesting that salicylate stimulated aerobic-dependent activity. No change in respiration or glycolysis followed the use of the parasubstituted congener; ortho-substitution may be a concomitant of chemical activity (17).

Salicylate did not diminish the viability of the number of cells remaining after 3 days in vitro, a finding consistent with shorter term in vitro studies $(18,19)$, as well as clinical observations.

The tissue culture media in this study contained fetal calf sera, and spontaneous synthesis of cellular nucleic acid and protein was called "normal." Salicylate diminished DNA synthesis in both "normal" and stimulated cells to a greater extent than RNA synthesis. This difference in suppression may reflect a greater sensitivity of DNA versus RNA polymerase to salicylate (20).

Salicylate reduced the incorporation of leucine into protein of human lymphocyte, as well as diaphragm and cell-free liver preparations from the rat (21).
Salicylate altered lymphocytes response to stimulation in a reversible manner; removal of the drug from the media allowed cells treated with PHA to reach the

\section{TABLE IV}

Recovery of Lymphocyte Response to PHA as Measured by RNA Synthesis

\begin{tabular}{llc}
\hline \multicolumn{2}{c}{ Additions to media } & \\
\cline { 2 - 3 } 0-24 hr & 24-72 hr & cpm/culture* \\
\hline Saline & Saline & $9149 \pm 1487$ \\
& Salicylate & $8842 \pm 751$ \\
Salicylate $\ddagger$ & Saline & $10,208 \pm 1640$ \\
& Salicylate & $8544 \pm 1638$ \\
PHA & Saline & $111,811 \pm 15,570$ \\
& Salicylate & $67,637 \pm 3694$ \\
PHA & Saline & $149,371 \pm 17,855$ \\
Salicylate & Salicylate & $68,405 \pm 7012$ \\
\hline
\end{tabular}

The recovery of lymphocyte response as measured by RNA synthesis. The media containing PHA, alone or with salicylate, salicylate, or saline alone was removed after $24 \mathrm{hr}$, and fresh media containing salicylate or saline was added (see text). The RNA synthesis of the treated cells was measured by uptake of tritiated uridine on the 3rd day of culture.

* Mean \pm SE.

‡ Sodium salicylate $30 \mathrm{mg} / 100 \mathrm{ml}$ final concentration. 
same level of RNA synthesis as found in those cultures to which PHA alone had been added. Reversible competition with NADP or respiratory dehydrogenases have been postulated as possible mechanisms of action of salicylate (22).

Addition of salicylate to leukocyte cultures decreased the number of mitosis (23) without inducing chromosomal aberrations (24). Conflicting data is available concerning the in vitro responsiveness of lymphocytes obtained from patients on therapeutic doses of salicylate (25). ${ }^{1}$ This investigation provides evidence that salicylate accelerates respiration and glycolysis of peripheral blood lymphocytes and reduces nucleic acid and protein synthesis in vitro without affecting cell viability. The effect of salicylate on other cellular components of the reticuloendothelial system is currently under investigation (26).

\section{ACKNOWLEDGMENTS}

It is a pleasure to acknowledge the generosity of Dr. Audrey Evans who allowed us free access to the oxygen electrode and to thank Mrs. Lola Williams and Mr. Ron Beahm for excellent technical assistance.

This investigation was supported by a grant from the Arthritis and Rheumatism Foundation-Illinois Chapter, and by U. S. Public Health Service Medical Research Training Grant 5-TOI-AM-05589-1.

\section{REFERENCES}

1. Ansell, B. M. 1963. Relationship of dosage and type of salicylate therapy to plasma levels in patients with rheumatoid arthritis. In International Symposium on Salicylates, Postgraduate Medical School of London, 1962. A. St. J. Dixon, M. J. H. Smith, B. K. Martin, and P. H. N. Wood, editors. Little, Brown and Company, Boston. 35.

2. Markowitz, M., and A. G. Kuttner. 1965. Rheumatic Fever: Diagnosis, Management, and Prevention. W. B. Saunders Company, Philadelphia. 107.

3. Gutman, A. B., T. F. Yu, and J. H. Sirota. 1955. A study by simultaneous clearance techniques of salicylate excretion in man. Effect of alkanization of the urine by bicarbonate administration; effect of probenecid. J. Clin. Invest. 34 : 711.

4. Mandel, H. G., N. M. Cambosos, and P. K. Smith. 1954. The presence of aspirin in human plasma after oral administration. J. Pharmacol. Exp. Ther. 112: 495.

5. Rowland, M., and S. Riegelman. 1968. Pharmacokenetics of acetylsalicylic acid after intravenous administration in man. J. Pharm. Sci. $57: 1313$.

6. Rowland, M., S. Riegelman, P. A. Harris, S. D. Sholkoff, and E. J. Eyring. 1967. Kinetics of acetylsalicylic acid disposition in man. Nature (London). 215: 413.

7. Skulachev, V. P. 1967. Transformation of energy in

\footnotetext{
${ }^{1}$ Pachman, I. M. 1970. Unpublished data.
}

respiratory chain: some experimental approaches. Int. Congr. Biochem. Abstr. 11: 305.

8. Brody, T. M. 1956. The action of sodium salicylate and related compounds on tissue metabolism in vitro. $J$. Pharmacol. Exp. Ther. 117: 39.

9. Penniall, R., G. Kalnitsky, and J. I. Roth. 1956. The effects of salicylic acid and related compounds on in vitro rat brain respiration. Arch. Biochem. 64: 390.

10. Packer, L., F. K. Austen, and E. C. Knoblock. 1959. Effect of salicylates on respiration and phosplorylation in heart mitochondria. Proc. Soc. Exp. Biol. Med. 100: 239.

11. Miyahara, J. T., and R. Karler. 1965. Effect of salicylate on oxidative phosphorylation and respiration of mitochondrial fragments. Biochem. J. 97: 194.

12. Jeffrey, S. W., and M. J. H. Smith. 1959. Some effects of salicylate on mitochondria from rat liver. Biochem. J. $72: 462$.

13. Pachman, L. M. 1967. The carbohydrate metabolism and respiration of isolated small lymphocytes. In vitro studies of normal and phytohemagglutinin stimulated cells. Blood J. Hematol. 30: 691.

14. Trinder, P. 1954. Rapid determination of salicylate in biological fluids. Biochem. J. 57: 301.

15. Kay, J. E., and A. Korner. 1966. Effect of cycloheximide on protein and ribonucleic acid synthesis in cultured human lymphocytes. Biochem. J. 100: 815.

16. Schneider, W. C. 1946. Phosphorus compounds in animal tissues. III. A comparison of methods for the estimation of nucleic acids. J. Biol. Chem. 164: 747.

17. Whitehouse, M. W. 1968. The molecular pharmacology of antiinflammatory drugs: some possible mechanisms of action at the biochemical level. Biochem. Pharmacol. 17 (Suppl.) : 293.

18. Forbes, I. J., and J. L. Smith. 1967. The effects of antiinflammatory drugs on lymphocytes. Lancet. 2: 334.

19. Smith, J. L., and I. J. Forbes. 1967. Use of human lymphocytes in the studies of drug action. Naturc (London). 215: 538.

20. Janakidevi, K., and M. J. H. Smith. 1969. Inhibition of nucleic acid polymerases by salicylate in vitro. J. Pharm. Pharmacol. 21: 401.

21. Dawkins, P. D., B. J. Gould, and M. J. H. Smith. 1966. Inhibitory effect of salicylate on the incorporation of $\mathrm{L}-\left[\mathrm{U}_{-}{ }^{14} \mathrm{C}\right]$ leucine into the proteins of rat tissue preparations in vitro. Biochem. J. 99: 703.

22. Smith, M. J. H., and J. A. Sturman. 1967. The mechanism of inhibition by salicylate of the pentose phosphate pathway in the human red cell. J. Pharm. Pharmacol. 19: 108.

23. Lim, W. N. 1966. Suppression by corticosteroids and salicylates of blast-cell transformation of human lymphocytes in vitro. Arthritis Rheum. 9: 521. (Abstr.)

24. Gantner, G. E., Jr., and J. Zuckner. 1965. Salicylate suppression and lymphocyte transformation. Arthritis Rheum. 8: 443. (Abstr.)

25. Eyring, E. F., B. K. Vig, and W. Tomblin. 1968. Some biological effects of aspirin and sodium salicylate on human leukocytes in vitro. Arthritis Rheum. 11: 821. (Abstr.)

26. Pashman, L. M. 1970. The effect of salicylate on the function and metabolism of peripheral blood leukocytes. Fed. Proc. 29: 492. (Abstr.) 